\title{
Pengaruh Metode Pembelajaran Problem Solving Berbantuan Software Geogebra Terhadap Kemampuan Komunikasi Matematis Siswa SMK Swasta PAB 12 Saentis Percut Sei Tuan
}

\author{
Rusmini' ${ }^{1}$, Donni Syahrial Hanafi Daulay ${ }^{2}$ \\ ${ }^{1}$ Lecturer, Potensi Utama University, Jl. K.L.Yos Sudarso Km. 6,5 No, 3-A Tanjung Mulia Medan, \\ Indonesia, 085270199246, email:rusminiponsan@yahoo.co.id \\ ${ }^{2}$ Lecturer, Potensi Utama University, Jl. K.L.Yos Sudarso Km. 6,5 No, 3-A Tanjung Mulia Medan, \\ Indonesia, 082166328208. Email:donnidaulay@gmail.com
}

\begin{abstract}
This study aims (1) to describe the effect a problem -solving learning methods assisted by GeoGebra Software on mathematical communication skills (KKM) of class XI Private SMK PAB 12 Saentis. (2) describe the problem-solving answer process for students solving the problem- solving methods assisted by GeoGebra and expository learning. The research method used is the quasi-experimental method. Samples were taken randomly and obtained 64 students who were likened to the experimental class and the control class. Tests of mathematical communication skills were measured through 4 items of description. Data analysis was performed using the t-test. Based on the results of the analysis, the problem solving learning method has a significant influence on mathematical communication skills. The process of student answers to the problem- solving learning method assisted by GeoGebra is better.
\end{abstract}

Keywords: Problem-Solving, Software GeoGebra,Mathematical Communication Skill

Abstrak-Penelitian ini bertujuan (1) mendeskripsikan pengaruh metode pembelajaran problem solving berbantuan Software GeoGebra terhadap kemampuan komunikasi matematis (KKM) siswa kelas XI SMK Swasta PAB 12 Saentis. (2) mendiskripsikan proses jawaban penyelesaian masalah siswa pembelajaran metode problem solving berbantuan GeoGebra dan pembelajaran ekspositori. Metode penelitian yang digunakan adalah metode quasi eksperimen. Sampel diambil secara random dan diperoleh 64 siswa yang diumpamakan sebagai kelas eksperimen dan kelas kontrol. Tes kemampuan komunikasi matematis diukur melalui 4 butir soal uraian. Analisis data dilakukan dengan menggunakan uji t. Berdasarkan hasil analisis, metode pembelajaran problem solving memberikan pengaruh yang signifikan terhadap kemampuan komunikasi matematis. Proses jawaban siswa pada metode pembelajaran problem solving berbantuan GeoGebra lebih baik.

Kata kunci: Problem Solving, Software GeoGebra , Kemampuan Komunikasi Matematis.

\section{PENDAHULUAN}

Pendidikan merupakan aspek yang sangat berharga, oleh karena itu aspek pendidikan harus mengalami perkembangan yang sangat pesat seiring dengan kemajuan teknologi. Banyak cara meningkatkan mutu pendidikan salah satu adalah dengan mendidik peserta didik dengan menggunakan metode yang memberikan motivasi pada peserta didik untuk lebih tertarik dan membuat kegiatan belajar dan mengajar menjadi menarik dan tidak membuat rasa bosan pada diri siswa. khususnya dalam belajar matematika. Matematika merupakan mata pelajaran yang bidang kajiannya abstrak dan memerlukan daya berpikir logis 
sehingga untuk menyampaikannya diperlukan suatu media agar siswa menjadi lebih termotivasi untuk belajar dan memahami materi yang disampaikan dan merangsang siswa untuk meningkatkan kemampuan komunikasi matematis. Banyak media pembelajaran yang digunakan pada pembelajaran matematika. Diantaranya adalah pembelajaran berbantuan software tertentu yang berguna untuk menyampaikan materi matematika yang abstrak menjadi lebih mudah dipahami. Namun ada kalanya peserta didik perlu diperkenalkan metode pembelajaran dengan menggunakan bantuan software tertentu dalam menyelesaikan masalah yang mana bertujuan untuk melatih daya kreativitas dan daya kritis siswa atau untuk memperoleh kemampuan dan kecakapan kognitif dalam memecahkan berbagai masalah secara logis atau rasional [12]. Dengan software siswa juga akan lebih mudah untuk mengkomunikasikan ide-ide matematikanya kepada orang lain. Begitu juga dalam hal siswa mengkomunikasikan bentuk-bentuk grafik fungsi kuadrat akan lebih mudah dan lebih cepat sehingga siswa akan lebih mengenal dan lebih banyak memahami bentuk-bentuk yang abstrak dalam matematika karena disini siswa berperan aktif, sehingga menggeser paradigma pembelajaran di kelas.

Salah satu software yang bisa digunakan bagi siswa untuk membantu pemecahan masalah adalah software GeoGebra. Software GeoGebra diantara software yang dirancang untuk membantu pemecahan masalah matematis, disini software digunakan sebagai evaluasi hasil kerja siswa yang dilakukan secara mandiri sehingga siswa bisa mengkoreksi hasil kerja mereka masing-masing sebelum dikoreksi oleh guru. Software GeoGebra memiliki keunggulan dan kelemahan. Salah satu keunggulan adalah software ini bukan software komersial namun software ini dapat diunduh dengan gratis di www.GeoGebra.com (Howenwaiter \& Lavicza $[6,7,8]$. Berdasarkan uraian di atas siswa sangat perlu diperkenalkan dengan "Metode Pembelajaran Problem-Solving Berbantuan Software GeoGebra bisa berpengaruh signifikan terhadap kemampuan komunikasi matematis siswa". Kemampuan Komunikasi Matematis Siswa di kelas bisa meningkat oleh karena dipengaruhi desain dari Lembar Kerja Siswa (LKS). Guru disini harus menjadi seseorang yang kreatif inspiratif sehingga menjadi motivasi bagi siswa [4]. Guru harus bisa mendesain LKS yang menarik sehingga menjadi motivasi bagi siswa untuk belajar lebih senang. LKS yang dirancang dengan memberikan solusi pemecahan masalah dengan berbantuan Softwre Geogebra akan mempermudah siswa dalam pemecahan masalah. LKS yang dirancang sebaik mungkin dengan penyelesaian secara manual serta dipandu penyelesaian dengan bantuan software Geogebra akan mempengaruhi kemampuan komunikasi matematis, karena pemecahan masalah berbantuan software GeoGebra akan mempermudah siswa untuk mengkomunikasikan dalam bentuk tulisan dari konsep-konsep matematika yang abstrak [16]. Hal senada dengan penelitian Ramadhani [13,14,15] bahwa LKS yang dirancang sesuai dengan materi dan karakter siswa (yang dikembangkan) akan meningkatkan kemampuan matematis siswa. Selain hal tersebut di atas ada beberapa faktor yang menjadi alasan dilakukannya pembelajaran dengan metode problem solving berbantuan software GeoGebra, pertama adalah tujuan umum pembelajaran matematika yang telah disusun oleh pemerintah melalui Badan Standar Nasional Pendidikan yang tertuang di Permendiknas No. 22 Tahun 2002, [3] dua diantaranya yaitu agar 
siswa mengkomunikasikan gagasan dengan simbol, tabel, diagram atau media lain untuk memperjelas keadaan atau masalah dan memiliki sifat menghargai kegunaan matematika dalam kehidupan, yaitu rasa ingin tahu, perhatian, dan minat dalam mempelajari matematika, serta sikap ulet dan percaya diri dalam pemechan masalah. Berdasarkan hal tersebut, kemampuan komunikasi matematis penting untuk diperhatikan, melalui komunikasi matematis siswa mengorganisasi dan mengkonsolidasi berpikir matematikanya baik secara lisan dan tulisan Selanjutnya alasan kedua yaitu pembelajaran banyak didominasi guru dan masih berlaku paradigma teacher center learning dan berdasarkan observasi penulis menunjukkan bahwa kemampuan komunikasi matematis siswa rendah, karena pada saat dilakukan tes diagnosis seperti masalah yang disajikan sebagai berikut.

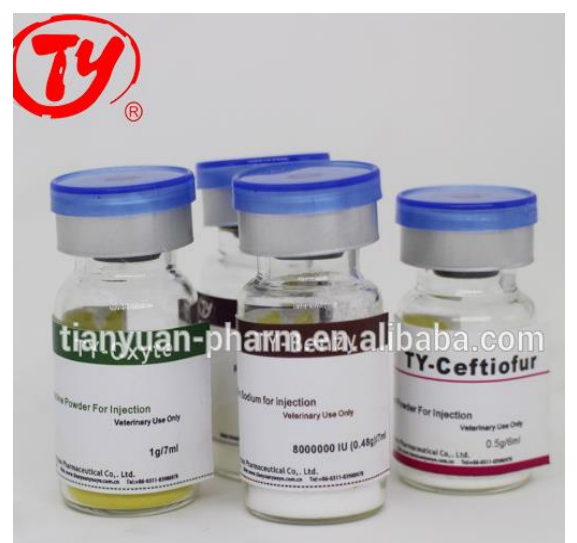

Gambar 1. Masalah yang disajikan pada bidang ekonomi

Penicilin berbentuk cair dibuat oleh suatu persahaan farmasi dan dijual borongan dengan harga Rp. 5000 perunit, Jika total biaya produksi untuk x unit adalah:

$\mathrm{C}(\mathrm{x})=5000000+800 \mathrm{x}+0,003 \mathrm{x}^{2}$. Dan jika kapasitas produksi terbesar dari perusahaan 400000 unit dalam waktu tertentu. Berapa banyak unit-unit penicillin harus dibuat dan dijual agar memperoleh keuntungan maksimum?

Dari 30 siswa yang menyelesaikan masalah hanya 2 orang siswa menjawab pemecahan masalah tersebut dan 28 siswa tidak mengerti tujuan dari pertanyaan tersebut.

Berdasarkan hal tersebut ada beberapa faktor penyebab, diantaranya yaitu pembelajaran yang dilakukan kurang dapat mengakomodir kemampuan komunikasi matematis siswa, soal-soal yang diberikan merupakan soal-soal yang rutin dengan kata lain kurang memfasilitasi Order Mathematical Thinking siswa sehingga siswa diberikan soal yang nonrutin mengalami kesulitan. Berdasarkan hal tersebut maka perlu diterapkan pembelajaran dengan metode problem solving berbantuan GeoGebra yang diharapkan bisa mempengaruhi kemampuan komunikasi matematis siswa. Hal tersebut diperkuat menurut pendapat Kilpatrik [17] bahwa dengan menggunakan metode problem-solving siswa dapat mengatasi kesulitan-kesulitan di dalam hidupnya. Hal senada menurut Rusmini \& Surya [16] dan menurut [22] bahwa pembelajaran dengan metode problem solving berbantuan software GeoGebra lebih efektif karena waktu yang digunakan lebih cepat dan siswa merasa lebih senang. Metode pembelajaran problem- solving 
berbantuan software GeoGebra berpengaruh signifikan terhadap kemampuan komunikasi matematis dan siswa termotivasi untuk belajar lebih baik.

\section{METODOLOGI PENELITIAN}

Penelitian ini dikategorikan penelitian eksperimen semu. Desain yang digunakan dalam penelitian ini meliputi tiga tahapan, yaitu : (1) Tahap penyusunan perangkat pembelajaran dan instrumen penelitian, (2) Tahap uji coba perangkat pembelajaran dan instrumen penelitian, (3) Tahap pelaksanaan eksperimen. Setiap tahapan dirancang sedemikian rupa sehingga diperoleh data yang valid sesuai dengan karakteristik variabel dan sesuai dengan tujuan penelitian.

Teknik pengambilan sampel yang digunakan dalam penelitian ini adalah simple random sampling, karena anggota populasi dianggap homogen [19]. Pengambilan sampel secara acak dengan cara undian, kelas yang terpilih sebagai sampel penelitian adalah siswa kelas XI-A sebagai kelas eksperimen dan siswa kelas XI-B sebagai kelas kontrol.

Bentuk desain penelitian quasi eksperimen yang digunakan adalah pretestposttest -control group design. Senada dengan penelitian [9]. Desain penelitian ini digunakan karena penelitian ini menggunakan kelas eksperimen dan kelas kontrol, tes dilakukan dua kali yaitu sebelum proses pembelajaran yang disebut pretest dan sesudah proses pembelajaran yang disebut posttest seperti desain di bawah ini :

Tabel 1. Desain Penelitian

\begin{tabular}{|l|c|c|c|}
\hline Kelompok & PreTest & Perlakuan & Post Test \\
\hline Eksperimen & $\mathrm{O}_{1}$ & $\mathrm{X}$ & $\mathrm{O}_{2}$ \\
\hline Kontrol & $\mathrm{O}_{3}$ & & $\mathrm{O}_{4}$ \\
\hline
\end{tabular}

Sumber: [10]

\section{Keterangan:}

$\mathrm{O}_{1}$ : Pre test yang diberikan pada kelas eksperimen sebelum proses pembelajaran

$\mathrm{O}_{2}$ : Post test yang diberikan pada kelas eksperimen setelah proses pembelajaran.

$\mathrm{O}_{3}$ : Pre test yang diberikan pada kelas kontrol sebelum proses pembelajaran

$\mathrm{O}_{4}$ : Post test yang diberikan pada kelas kontrol setelah proses pembelajaran

$\mathrm{X}$ : Penerapan metode problem- solving berbantuan software GeoGebra

a. Tahapan pada metode problem -solving yang dimodifikasi menurut [2] adalah sebagai berikut:

1. Tahap persiapan .

Tahap persiapan, disini guru menarik perhatian dengan berdoa yang bertujuan mengajak siswa mempersiapkan secara moril atau kejiwaan dengan bimbingan dan lindungan sang pencipta atau memusatkan segenap kekuatan pada suatu situasi belajar atau kosentrasi [18]

2. Memahami Masalah

Tahap merancang rencana, siswa mulai menyusun langkah-langkah apa yang akan digunakan dalam menyelesaikan soal berbantuan software Geogebra namun pada final penyelesaian siswa juga diharapkan membuat langkah-langkah penyelesaian secara manual. Disini fungsi Software Geogebra sebagai evaluasi, sebagai pemahaman lebih mendalam tentang obyek matematika yang bersifat abstrak [21] atau sebagai panduan untuk 
meingkatkan kemampuan komunikasi matematis siswa dalam tahap penyelesaian sehingga siswa merasa yakin dengan yang mereka cari secara manual, selain itu juga mempercepat waktu penyelesaian soal. Pada saat siswa membandingkan hasil secara bekerja sama dengan teman kelompoknya disini tercipta suatu komunikasi dan menghasilkan ide-ide matematik dari setiap siswa yang artinya komunikasi sangat penting untuk efektifitas pekerjaan [20] sehingga suasana pembelajaran menjadi asyik dan siswa tidak akan merasa jenuh dan bosan. Disamping itu guru memberikan arahan tentang materi yang berhubungan dengan soal.

3. Tahap melaksanakan rencana, siswa menyelesaikan masalah /soal yang dihadapi dengan berbantuan software Geogebra yang telah dipersiapkan, guru membagi menjadi beberapa kelompok agar mereka saling berbagi informasi.

4. Melihat kembali, guru mengulas kembali soal yang telah dikerjakan agar siswa lebih mengerti.

b. Penampilan hasil, siswa menampilkan hasil diskusi yang telah dilakukan dengan bantuan Software GeoGebra

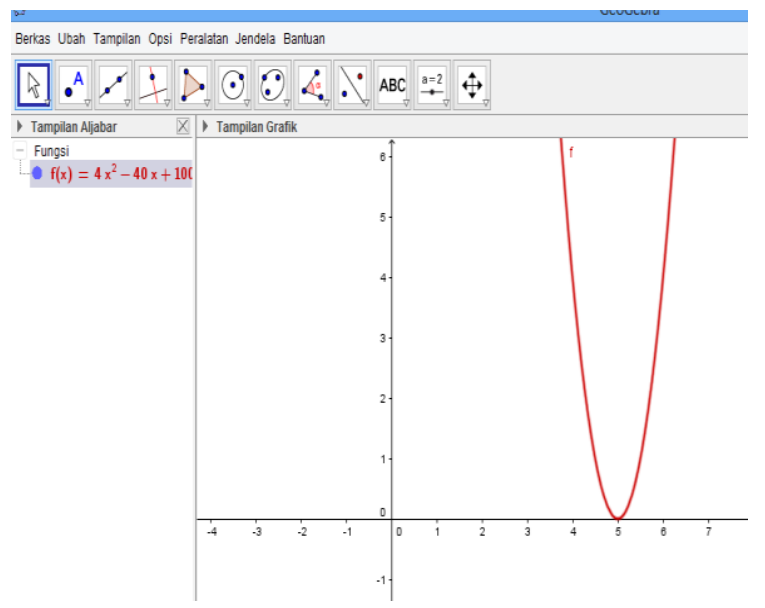

Gambar 2. Gambar grafik fungsi kuadrat berbantuan software Geogebra

Adapun langkah-langkah pemecahan masalah berbantuan GeoGebra [23]:

a. Program Geogebra dibuka maka akan tampil Gambar 3 a

b. Pada bilah masukkan ketik model matematika dari fungsi kuadrat $f(x)=4 x^{\wedge} 2-$ $40 \mathrm{x}+100$ tekan enter.

c. Maka akan muncul Gambar 3 b

d. Untuk mendapatkan nilai ekstrim atau nilai minimum fungsi cukup mengetik pada bila masukkan nilai ekstrim[f] enter maka akan tampil Gambar $3 \mathrm{c}$

e. Untuk merubah tampilan grafik (warna yang kita inginkan)

f. Kita klik pada grafik dua kali maka akan tampil Gambar 4 a

g. Klik properti dan akan tampil Gambar $4 \mathrm{~b}$

h. Selanjutnya klik warna yang kita inginkan. Bila diklik warna merah dan klik format akan tampil Gambar $4 \mathrm{c}$ dan geser tebal garis pada angka 11 maka akan tampil seperti Gambar $4 \mathrm{~d}$

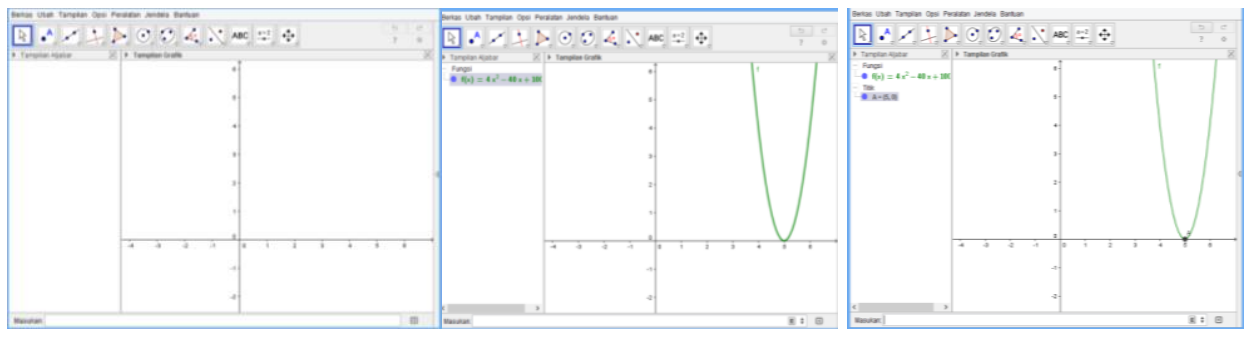



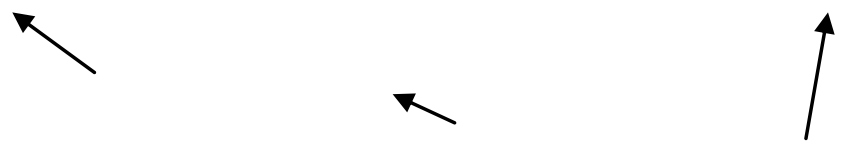

b

Gambar 3. Memecahkan Masalah Berbantuan Geogebra

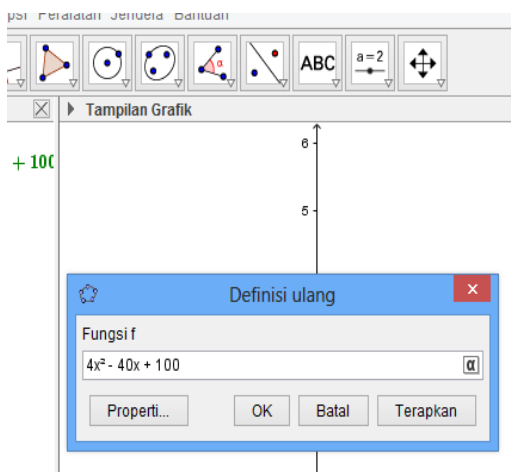

a

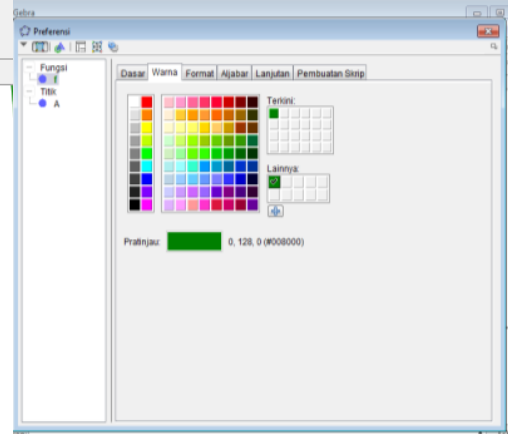

b

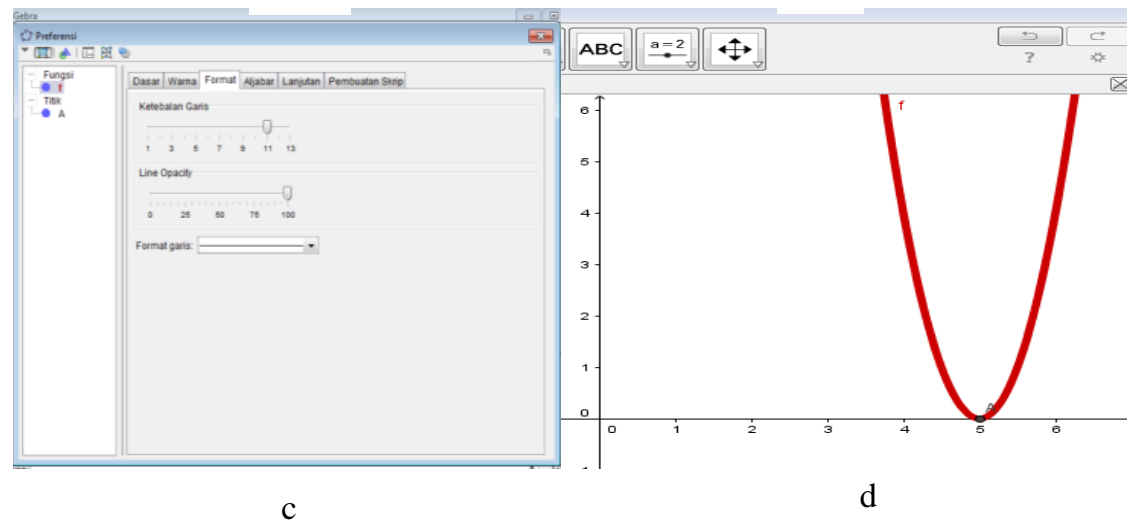

Gambar 4. Langkah-Langkah Merubah Tampilan grafik

Berdasarkan hasil kerja siswa maka dapat diambil kesimpulan bahwa kemampuan komunikasi matematis siswa meningkat karena indikator kemampuan komunikasi matematis siswa menurut hasil survey PISA, Stacey dan William tahun 2012 [5] terlihat pada hasil kerja siswa yang mana telah terpenuhi hal-hal sebagai berikut.

a. Merumuskan situasi matematis dengan cara membaca, memecahkan kode, dan membuat pengertian kalimat, pertanyaan, tugas, objek, gambar, atau animasi dalam bentuk sebuah model mental dari situasi.

b. Memanfaatkan konsep matematis, fakta, prosedur, dan alasan dengan cara mengeluarkan sebuah solusi, menunjukkan pada saat pengerjaan melibatkan pencapaian solusi dan meringkas dan menyajikan hasilnya secara matematis.

c. Menginterpretasikan,menerapkan dan mengevaluasi hasil secara matematis, dengan cara membangun dan mengkomunikasikan penjelasan dan pendapatpendapat dalam kaitan dengan masalah. 


\section{HASIL DAN PEMBAHASAN}

Berdasarkan penerapan metode pembelajaran problem-solving berbantuan software GeoGebra maka didapatlah hasil sebagai berikut.

\subsection{Hasil Kemampuan Komunikasi Matematis Siswa.}

Hasil penelitian menunjukkan bahwa hasil posttest kemampuan komunikasi matematis siswa yang memperoleh pembelajaran matematika berbantuan Software GeoGebra meningkat secara signifikan, senada dengan penelitian Nehe dkk [11] pembelajaran menggunakan software Autograph yang punya konsep hampir sama dengan software GeoGebra berpengaruh signifikan. Perlakuan yang diberikan memberikan pengaruh yang signifikan terhadap skor postes dan peningkatan kemampuan komunikasi matematis dideskripsikan pada Tabel 2 sebagai berikut.

Tabel 2. Deskripsi Hasil Kemampuan Komunikasi Matematis Pre Test dan Post Test Pada Kelas Eksperimen

\begin{tabular}{|c|c|c|}
\hline Kriteria & \multicolumn{2}{|c|}{ Kemampuan Komunikasi Matematis } \\
\hline & Pre Test & Post Tes \\
\hline Nilai Tertinggi & 78,00 & 100 \\
\hline Nilai Terendah & 50.00 & 70 \\
\hline Rata-Rata & 63,75 & 86,00 \\
\hline
\end{tabular}

Sumber : Data Penelitian 2019

Berdasarkan Tabel 2 menunjukkan bahwa rata-rata kemampuan komunikasi matematis siswa adalah sebesar 63,75 untuk pretes dan posttes sebesar 86,00 . Jika dikategorikan berdasarkan tingkat penguasaan siswa kemampuan komunikasi matematis siswa pada hasil posttest pada kelas eksperimen dapat dilihat pada Tabel 3 berikut.

Tabel 3. Tingkat Penguasaan KKM Siswa Hasil Posttest Pada Kelas Eksperimen

\begin{tabular}{|l|l|c|c|l|}
\hline No & Interval Nilai & Jumlah Siswa & Persentasi & Kategori \\
\hline 1 & $0 \leq S K K M<45$ & 0 & $0 \%$ & Sangat Kurang \\
\hline 2 & $45 \leq$ SKKM $<65$ & 0 & $0 \%$ & Kurang \\
\hline 3 & $65 \leq S K K M<75$ & 4 & $12,50 \%$ & Cukup \\
\hline 4 & $75 \leq$ SKKM $<90$ & 15 & $46,88 \%$ & Baik \\
\hline 5 & $90 \leq$ SKKM $<100$ & 13 & $40,63 \%$ & Sangat Baik \\
\hline
\end{tabular}

Sumber: [1] SKKM: Skor Kemampuan Komunikasi Matematis

Berdasarkan Tabel 3 diperoleh bahwa, tidak ada siswa yang memperoleh kategori sangat kurang (0\%) yang ,memperoleh kategori kurang tidak ada (0\%), yang memperoleh kategori cukup sebanyak 4 siswa $(12,50 \%)$ yang memperoleh kategori baik sebanyak 15 siswa (46,88 \%) yang memperoleh kategori sangat baik ada 13 siswa (40,63\%). Untuk lebih jelasnya dapat dilihat pada diagram berikut 


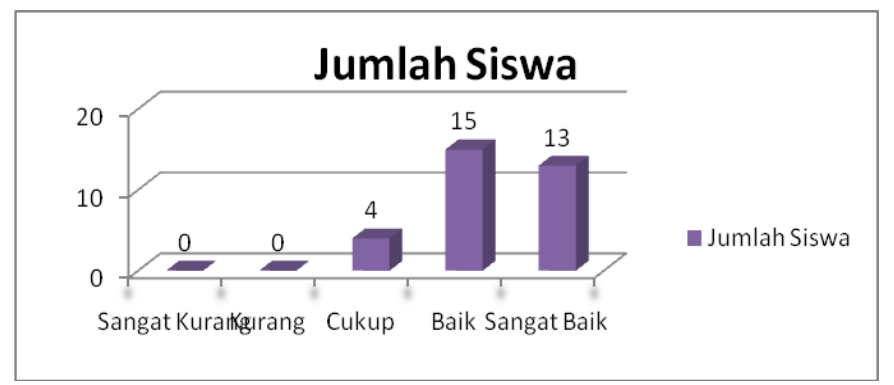

Gambar 5. Skor Kemampuan Komunikasi Matematis Siswa Post Test Pada Kelas Eksperimen

Selanjutnya tingkat penguasaan siswa kemampuan komunikasi matematis siswa pada hasil posttest kelas kontrol dapat dilihat pada Tabel 4 berikut.

Tabel 4. Tingkat Penguasaan KKM Siswa Hasil Post-test Pada Kelas Kontrol

\begin{tabular}{|c|l|c|c|l|}
\hline No & Interval Nilai & Jumlah Siswa & Persentasi & \multicolumn{1}{|c|}{ Kategori } \\
\hline 1 & $0 \leq S K K M<45$ & 0 & $0 \%$ & Sangat Kurang \\
\hline 2 & $45 \leq$ SKKM $<65$ & 7 & $21,88 \%$ & Kurang \\
\hline 3 & $65 \leq$ SKKM $<75$ & 7 & $21,88 \%$ & Cukup \\
\hline 4 & $75 \leq$ SKKM $<90$ & 14 & $43,75 \%$ & Baik \\
\hline 5 & $90 \leq$ SKKM $<100$ & 4 & $12,50 \%$ & Sangat Baik \\
\hline
\end{tabular}

Sumber: [1]

Berdasarkan Tabel 4 diperoleh bahwa, tidak ada siswa yang memperoleh kategori sangat kurang (0\%) yang ,memperoleh kategori kurang sebanyak 7 siswa $(21,88 \%)$, yang memperoleh kategori cukup sebanyak 7 siswa $(21,88 \%)$ yang memperoleh kategori baik sebanyak 14 siswa (43,75 \%) yang memperoleh kategori sangat baik sebanyak 4 (12,5\%). Untuk lebih jelasnya dapat dilihat pada diagram berikut.

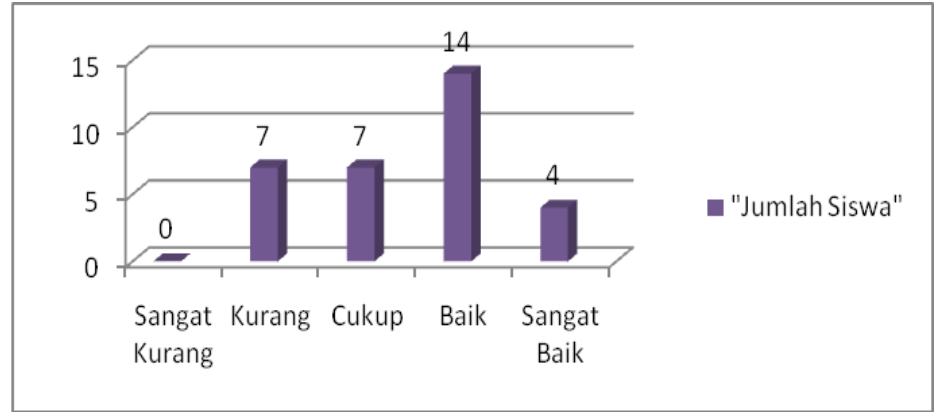

Gambar 6. Skor Post Test Kemampuan Komunikasi Matematis Siswa Pada Kelas Kontrol

Selanjutnya, hasil ketuntasan secara klasikal kemampuan komunikasi matematik siswa pada kelas eksperimen dan kelas kontrol dapat dilihat pada Tabel 5 berikut. 
Tabel 5. Tingkat Ketuntasan Klasikal KKM Pada Kelas Eksperimen Dan kelas Kontrol

\begin{tabular}{|l|c|c|c|c|}
\hline \multirow{3}{*}{ Kategori } & \multicolumn{3}{|c|}{ Kemampuan Komunikasi Matematis Siswa } \\
\cline { 2 - 5 } & \multicolumn{2}{|c|}{ Eksperimen } & \multicolumn{2}{c|}{ Kontrol } \\
\cline { 2 - 5 } & Jumlah Siswa & Ketuntasan & Jumlah Siswa & Ketuntasan \\
\hline Tuntas & 28 & $87,5 \%$ & 18 & $56,25 \%$ \\
\hline Tidak Tuntas & 4 & $12,50 \%$ & 14 & $43,75 \%$ \\
\hline Jumlah & 32 & $100 \%$ & 32 & $100 \%$ \\
\hline
\end{tabular}

Sumber : Data Penelitian 2019

Berdasarkan Tabel 5 bahwa tingkat ketuntasan klasikal kemampuan komunikasi Matematis pada pembelajaran Kelas Eksperimen sebesar 87,5 \% dan tidak tuntas $12,5 \%$ dan untuk kelas kontrol tuntas sebesar 56,25 \% , tidak tuntas sebesar 43,75 \% secara grafik dapat dilihat pada Gambar 3 sebagai berikut.

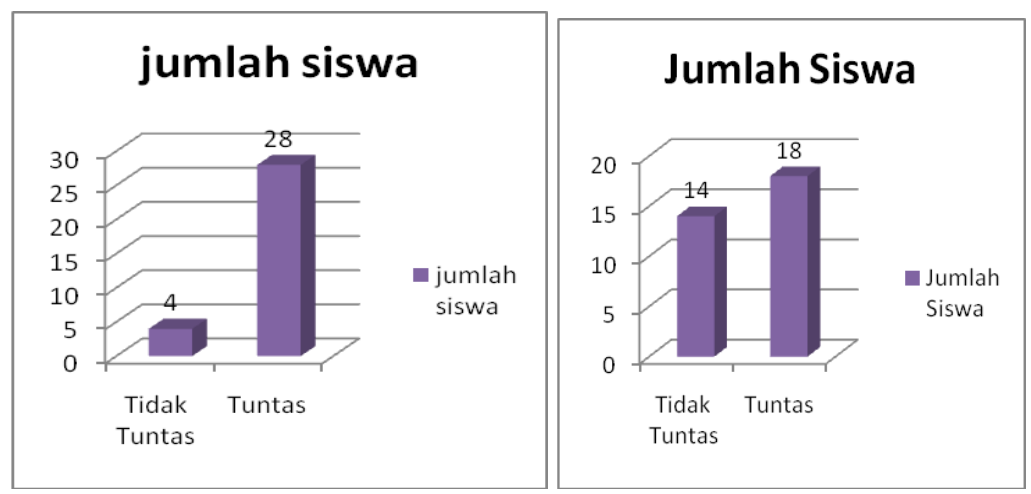

Gambar 7. Ketuntasan Klasikal Pada Kelas Eksperimen Dan Kelas Kontrol

Berdasarkan hasil ketuntasan secara klasikal yang disajikan pada Tabel 4 dan Tabel 5 serta berdasarkan Gambar 3 dan Gambar 4 dapat disimpulkan bahwa pembelajaran problem- solving berbantuan software GeoGebra pada kelas eksperimen ketuntasan klasikalnya lebih tinggi dari kelas kontrol berarti kemampuan komunikasi matematis siswa pada kelas kontrol lebih baik yang artinya metode pemelajaran problem- solving berbantuan software GeoGebra berpengaruh signifikan terhadap kemampuan komunikasi matematis siswa. Senada dengan penelitian [24] metode problem- solving sangat efektif pada pembelajaran matematika di kelas.

Tabel 6. Rekapitulasi Hasil Perhitungan Uji Hipotesis

\begin{tabular}{|c|c|c|c|c|c|}
\hline Kelompok & Sampel & $\mathbf{t}_{\text {hitung }}$ & $\mathbf{t}_{\text {tabel }}$ & Hipotesis & Kesimpulan \\
\hline Eksperimen & 32 & 5,450 & 2,000 & $t_{\text {hitung }}>t_{\text {tabel }}$ & Terima $\mathrm{H}_{\mathrm{a}}$ \\
\hline Kontrol & 32 & & & & \\
\hline
\end{tabular}

Sumber:[19]

Berdasarkan kriteria pengujian pada Tabel 6 rekapitulasi uji hipotesis didapatkan thitung $=5,450>t_{\text {tabel }}=2,000$ berarti terima $\mathrm{H}_{\mathrm{a}}$. 
Hipotesis kedua yang diajukan adalah:

$\mathrm{H}_{0}: \mu_{1} \leq \mu_{2}$ : rata-rata kelas eksperimen lebih kecil atau sama dengan rata-rata kelas kontrol artinya tidak ada pengaruh yang signifikan pada pembelajaran dengan metode problem-solving berbantuan software GeoGebra terhadap kemampuan komunikasi matematis di SMK Swasta PAB 12 Saentis.

$\mathrm{H}_{\mathrm{a}}: \mu_{1}>\mu_{2}$ : rata-rata kelas eksperimen lebih dari rata-rata kelas kontrol artinya ada pengaruh yang signifikan pada pembelajaran dengan metode problem- solving berbantuan software GeoGebra terhadap kemampuan komunikasi matematis di SMK Swasta PAB 12 Saentis.

Hipotesis juga diperkuat dengan uji gain ternormalisasi dengan menggunakan penguasaan komunikasi matematis siswa yang dilihat dari hasil belajar kedua kelas, yaitu kelas eksperimen dan kelas kontrol. Hasil uji gain ternormalisasi adalah sebagai berikut:

Tabel 6. Hasil Uji Indek-Gain Kemampuan Komunikasi Matematis Siswa.

\begin{tabular}{|l|c|c|l|}
\hline $\begin{array}{c}\text { Rentang Indek } \\
\text { N-Gain }\end{array}$ & \multicolumn{3}{|c|}{ Hasil } \\
\cline { 3 - 4 } & Kontrol & Eksperimen & Kriteria \\
\hline $\mathrm{g}>0,7$ & 0,31 & 0,60 & Tinggi \\
\hline $0,7 \geq \mathrm{g}>0,3$ & & & Sedang \\
\hline $\mathrm{g} \leq 0,3$ & & & Rendah \\
\hline
\end{tabular}

Sumber : Modifikasi [10]

Berdasarkan hasil uji Indek N-Gain Kemampuan Komunikasi Matematis Siswa pada kelas kontrol sebesar 0,31 kategori sedang dan pada kelas eksperimen sebesar 0,60 kategori sedang juga, namun bila dilihat dari besarnya angka maka pada kelas eksperimen lebih tinggi artinya kemampuan komunikasi matematis siswa pada pembelajaran dengan metode problem-solving berbantuan software GeoGebra hasilnya lebih baik artinya pembelajaran problem-solving berbantuan software GeoGebra mempunyai pengaruh yang signifikan terhadap kemampuan komunikasi matematis. Walaupun indeks Gain belum tergolong kategori tinggi, hal tersebut bisa saja dikarenakan siswa belum terbiasa menggunakan software GeoGebra dalam pemecahan masalah matematis.

\section{KESIMPULAN DAN SARAN}

Berdasarkan hasil dan pembahasan pada penelitian ini maka dapat disimpulkan:

a. Metode Pembelajaran problem-solving berbantuan software GeoGebra berpengaruh signifikan terhadap kemampuan komunikasi matematis siswa.

b. Motivasi belajar dan respon siswa lebih baik, karena siswa merasa senang di saat pembelajaran dan suasana lebih kondusif.

c. Waktu yang digunakan siswa untuk memecahkan masalah matematis lebihcepat.

d. Pembelajaran lebih efektif, namun ada kendala bagi sekolah yang tidak memiliki laboratorium komputer karena siswa tidak semua memiliki fasilitas komputer pribadi. 
e. Dengan pembelajaran berbantuan Software GeoGebra kita turut andil pada pengembangan pembelajaran matematika berbasis ICT.

f. Pembelajaran berbantuan Software GeoGebra bisa sebagai alternatif pembelajaran pada materi yang lain.

g. Proses jawaban siswa lebih baik.

\section{ACKNOWLEDGMENT / UCAPAN TERIMA KASIH:}

1. Penelitian ini didanai oleh Kemenristekdikti-DRPM pada skema hibah PDP tahun pendanaan 2019

2. Universitas Potensi Utama yang telah memberi kesempatan melakukan penelitian ini.

3. SMK Swasta PAB 12 Saentis Percut Sei Tuan yang telah memberikan izin sebagai lokasi penelitian ini.

\section{DAFTARPUSTAKA}

[1] Arikunto, S. (2012). Dasar-Dasar Evaluasi Pendidikan Edisi 2. Jakarta: Bumi Aksara.

[2] Badger M.S, etc (...) Teaching Problem Solving In Undergraduate Mathematics. Maths, Stats \& QR Network: National HE STEM Program Conventry University.

[3] Depdiknas. (2002), Pengembangan Sistem Pendidikan Tenaga Kependidikan Abad ke-21. Jakarta : Depdiknas.

[4] Fanany. El (2013). Guru Sejati Guru Idola. Juru Sukses Menjadi Guru Kreatif Inspiratif yang Dicintai dan Dikenang Sepanjang Masa. Yogyakarta : Araska.

[5] Hendriana. H, Rohaeti. E, Sumarmo (2017). Hard Skills dan Soft Skill Matematik Siswa. PT. Refika Aditama: Bandung.

[6] Howenwaiter \& Lavicza (2007). Introduzione a GeoGebra. Creative Commons AttributionNoncommercial-Share Alike. Versione italiana.

[7] Howenwaiter dkk. (2004). Combination of dynamic geometry, algebra and calculus in the software system GeoGebra. University of Salzburg, Departement of Mathematics and Computer Science Education, HellbrunnerstraBe 34, A-5020 Salzburg, Austria; e-mail: markus. hohenwarter@sbg.ac.at;web:http://www.geogebra.at

[8] Howenwaiter dkk. (2008). Teaching and Learning Calculus with Free Dynamics And Anallisis (Mea). Jurnal Kreano. Volume 5 No.2 Bulan Desember tahun 2014.

[9] Juanda. M, Ikhsan. M. (2014). Peningkatan Kemampuan Pemecahan Masalah Dan Kemampuan Komunikasi Matematis Siswa SMP Melalui Model Pembelajaran Means Mathematics Software GeoGebra. Research and development in the teaching and learning of calculus ICME 11, Monterrey, Mexico 2008.

[10] Lestari E.K, Yudhanegara (2015) Penelitian Pendidikan Matematika. Bandung : Refika Aditama.

[11] Nehe M. dkk (2017). The Development Of Learning Device Based Contextual Teaching Learning (CTL) Assisted Autograph To Improve The Ability Of Problem Solving Mathematics Class X SMA Negeri 1 Teluk Dalam. Journal Education And Parctice. Volume. 8, No. 19, 2017

[12] Rasyidin Al, Wahyuddin. N.N. (2011). Teori Belajar dan Pembelajaran. Medan: Perdana Publishing.

[13] R. Ramadhani. (2016). Pengembangan Perangkat Pembelajaran Matematika yang Berorientasi pada Model Problem Based Learning. Jurnal Matematika Kreatif Inovatif. Kreano 7 (2) (2016):116-122

[14] R.Ramadhani. Narpila. S.D. (2018). Pengembangan lembar Kerja Siswa Menggunakan Model Based Learning Berbasis Budaya Lokal Pada Siswa Kelas XI SMA YPK Medan. Jurnal Akrab Juara. Volume 3 Nomor 3 Edisi Agustus 2018 (44-54).

[15] R.Ramadhani dkk (2018). The Development of Student Worksheet and Test Instrument for Statistical Thinking Skill Based On Local Culture and Accordance With Curiculum 2013 in Indonesia: Design Reseach Stage. Advances in Social Science Education and Humanities 
Research (ASSEHR), Volume 208. $1^{\text {st }}$ International Conference on Social Sciences and Interdisciplinary Studies (ICSS)

[16] Rusmini \& Surya E.(2019). Development of Oriented Student Activity Sheets Problem-Based Learning Approaches Assisted by GeoGebra Software to Improve Metacognition Ability of Private Vocational High School PAB 12 Saentis.Journal Education \& PracticeVolume 10. No.9, 2019. p.166-170

[17] Slameto. (2010). Belajar dan Faktor-faktor yang Mempengaruhinya. Jakarta:PT Raja Gravindo Persada.

[18] Sardiman. (2010). Interaksi dan Motovasi Belajar Mengajar. Jakarta: Rajawali Pers.

[19] Sugiyono. (2010). Statistika untuk Penelitian. Bandung: Alfabeta.

[20] Suciati. (2016) Psikologi Komunikasi Sebuah Tinjauan Teoritis dan Perspektif Islam. Yogyakarta: Litera Yogyakarta.

[21] Sundayana. (2016). Media Dan Alat Peraga Dalam Pembelajaran Matematika untuk guru, orang tua, dan para pecinta matematika. Bandung Alfabeta.

[22] Supriadi N (2015) Pembelajaran Geometri Berbasis Geogebra Sebagai Upaya Meningkatkan Kemampuan Komunikasi Matematis. Al-Jabar-Jurnal Pendidikan Matematika Vol. 6, No. 2, 2015, Hal 99-109

[23] Syahbana A (2016) Belajar Menguasai GeoGebra (Program Aplikasi Pembelajaran Matematika). Palembang : Noer Fikri

[24] Suprapto E. Kuswara. K.M (2019). The Effect of Problem-Based learning Strategy on Student Learning Outcomes of SMK with Differrent Achievment Motivation. Journal Education and Practice. Volume 10.No.1. 2019 